\title{
Corporal Punishment of Children in Schools: Way Forward
}

\author{
Tolu O. Okoruwa \\ Federal College of Education, Abeokuta, Nigeria
}

\begin{abstract}
Advancement in science and technology calls for enabling students making informed decisions in the context of socio-scientific issues (SSI). This study aimed at exploring the efficacy of teaching science through SSI- based argumentation for improving grade-IX students' argumentation skills with particular focus on the quality and complexity of argumentation. A pre-experiment; pre-post-test design was employed. All of the grade-IX students $(n=44)$ of biology group in an urban public school of Karachi, Pakistan were recruited as a sample. After being taught a unit of eight lessons (45-minutes each) on genetics, students were explicitly engaged in oral and written argumentation for further four sessions (45-minutes each). Data were collected through writing frames before, and after the intervention to gather evidence on progress, students have made in SSI- based argumentation. The data were analysed for complexity and quality of argumentation using the pre-defined analytical frameworks. The findings indicated an overall improvement in complexity of students' argumentation with significant difference (Wilcoxon $W=553 ; Z=-4.94 ; p<0.01)$. The magnitude of difference fell in the category of large effect $(r=$ 0.80). Similarly, a significant difference (Wilcoxon $W$ = 528; $Z=-5.00 ; p<0.01)$ was observed in the quality of students' argumentation with a large $(r=$ 0.832) effect size. Moreover, a model of teaching and learning science through SSI- based argumentation has also been developed.
\end{abstract}

\section{Introduction}

Childhood is the period when one's personality is molded into what they become later in life. Despite its profoundly negative effects on survivors, corporal punishment of children is, in many instances, a socially and culturally accepted form of 'discipline' in homes and schools in many parts of the world [1]. Even though it has been outlawed in recent decades in 128 countries including all of Europe, most of South America, as well as in Canada, Japan, South Africa, New Zealand and several other countries, it remains commonplace in a number of countries in Africa, Southeast Asia, and the Middle East [2]. There is a need, therefore, to take a closer look at this means of discipline in order to encourage more constructive ones in the best interest of the child.

\section{School corporal punishment}

School corporal punishment refers to causing deliberate pain or discomfort in response to undesired behavior by students in schools. Examples include the hitting of a person with the hand (smacking, slapping and spanking) or an object such as a cane, whip, shoe, wooden ladle, slipper or belt [3]. It is also kicking, scalding or burning, shaking or throwing of a person with the intention of inflicting pain on them. Pinching or pulling the hair or ear, forcing one to sit in uncomfortable or undignified positions, forced ingestion (for example, forcing one to swallow hot spices), or forcing one to take excessive physical exercise as a way of discipline is tantamount to corporal punishment [4]. Caning is a form of corporal punishment consisting of a number of hits (known as "strokes" ) with a cane, generally applied to the offender's bare or clothed buttocks, hand(s), soles of the feet and other parts of the body. Even though it has been outlawed in some countries of the world, it still remains legal in many homes and schools in many others. Even in some countries where it is no longer legal, it is still in common use [5].

\subsection{Corporal punishment: a violation of child rights}

Corporal punishment violates children's human rights to physical integrity and human dignity, as upheld by the UN Convention on the Rights of the

Child [6]. UNICEF, UNESCO and other international human rights treaties, therefore, require member nations ensure its prohibition in all settings of children's lives. To this end, many countries have completely prohibited corporal punishment of children in schools, including Sweden (1979), Argentina (2014), Togo (2007), Austria (1989), Germany (2000) and Greece (2005) [15]. The educational system in Finland has been proclaimed one of the best in the world for children, yet the country has been able to achieve this standard without using corporal punishment on children for 34 years now. However, a lot still needs to be done because only $10 \%$ of the world's children are fully protected by law from all forms of corporal punishment [15].

Nepal is the first country in South Asia to prohibit corporal punishment on children in all settings. Nepal adopted the Act relating to Children 
2018 which explicitly prohibits corporal punishment of children in all settings. It was certified by the President on 18 September 2018 and has now come into effect [14].

Corporal punishment was prohibited in Ireland in 1982 but erring teachers only became liable to criminal prosecution in 1997. Similarly, as from 1996, any teacher who administered corporal punishment in South African schools could be convicted for assault. Though corporal punishment has been banned in countries such as Thailand, Japan and India, it is still in practice today because erring teachers are neither prosecuted nor convicted. Worse still, corporal punishment is presently a common practice in schools in South Korea, Malaysia, Myanmar, Tanzania, Uganda and most African countries. It is high time drastic action is taken in these and other countries of the world where children are being denied their rights to physical integrity and human dignity through corporal punishment towards its discontinuation forthwith.

\subsection{Effects of corporal punishment on children}

Corporal Punishment is counterproductive, relatively ineffective, dangerous and harmful according to research findings $[7,8,9,12]$. The general effects include: (i) It lowers their self-esteem (ii) It teaches children to be victims. (iii) It interferes with the learning process (iv) It discourages the use of reasoning by precluding dialogue and reflection (v) It hampers the capacity to understand the relationship between behavior and its consequences (vi) Children can suffer from accidental physical injuries or even death (vii) It makes children feel lonely, angry, sad and abandoned (viii) It promotes a negative view of other people and of society as a threatening place; and difficulties with social integration (ix) It creates barriers that impede parent-child communication $(x)$ It teaches that violence is an acceptable way of solving problems.

In school, in particular, the effects include: (i) Poor academic performance (ii) View of the learning environment as unwelcoming (iii) Increased aggressive and disruptive classroom behavior (iv) Vandalism (v) Poor attention span (vi) Increased dropout rate (vii) School avoidance and phobia (viii) Lower self-esteem (ix) Anxiety towards learning (x) more restricted vocabulary (xi) lower IQ.

Furthermore, physically punished school children are reported to have sustained serious injuries to the point of needing medical attention. These injuries have included bruises, abrasions, broken bones, whiplash injury, muscle damage, brain injury, sciatic nerve damage, extensive hematomas, lifethreatening fat hemorrhage and even death $[9,10]$

\subsection{Contributing factors to the use of corporal punishment}

Advocates of school corporal punishment argue that as opposed to suspension, it provides an immediate response to the teacher's discipline and that the student does not miss classroom activities. Factors most strongly associated with the use of corporal punishment by teachers are: experience with physical punishment as a child, lack of knowledge about child development, socioeconomic status, parental education, and religious ideology [3]. Others include anger reactions to children's behavior (attribution of the child's behavior to willful defiance), lack of knowledge of positive strategies for child discipline, marital and parenting stress. Pediatricians also found three broad rationales for the use of corporal punishment in schools: beliefs, based in traditional religion, that adults have a right, if not a duty, to physically punish misbehaving children; a disciplinary philosophy that corporal punishment builds character, being necessary for the development of a child's conscience and their respect for adult authority figures; and beliefs concerning the needs and rights of teachers, specifically that corporal punishment is essential for maintaining order and control in the classroom [9]. However, there is a lack of empirical evidence showing that corporal punishment leads to better control in the classroom, neither was it found to enhance moral character development, increase students' respect for teachers or other authority figures, nor offer greater security for teachers [10].

\section{Demerits of punishment}

Punishment is used for the purposes of controlling and retribution. It interferes with the development of internal controls by teaching children that it is someone else's responsibility to control them and decide what behavior is "bad" and what the consequences will be. Punishment causes children to focus their attention and anger toward an "unfair" adult rather than on learning to be responsible for their own actions. It also validates fear, pain, intimidation and violence as acceptable methods of resolving conflict. Children could become immune to punishment over time, causing adults to increase the degree of force, which ultimately results in child abuse. Caning is punitive rather than corrective. Therefore, it should be discouraged.

\section{Benefits of discipline}

Young children are not criminals; therefore, their mistakes call for a corrective disciplinary response. 
Discipline is proactive, rather than reactive. To discipline a child means to offer a child a framework, a set of boundaries to live with. That is, offering a framework that will allow the child to grow and blossom as a person and to become who they truly are. The goal of positive discipline is to teach, train and guide children so that they learn, practice selfcontrol and develop the ability to manage their emotions, and make wise choices regarding their personal behaviour. Positive discipline helps children understand that their choices, actions and behaviours all have consequences and that it is the choices the child makes that determines the consequences thereby letting them realize that they have more control of their lives. Moreover, parents and caregivers can remain calmer and experience less stress or guilt.

Table 1. Differences between Discipline and Punishment

\begin{tabular}{|c|l|l|}
\hline S/No & \multicolumn{1}{|c|}{ Discipline } & Punishment \\
\hline 1 & Motivates & Punishes \\
\hline 2 & $\begin{array}{l}\text { Aims to empower } \\
\text { children }\end{array}$ & $\begin{array}{l}\text { Aims to create } \\
\text { obedient } \\
\text { children }\end{array}$ \\
\hline 3 & Child centered & $\begin{array}{l}\text { Teacher } \\
\text { centered }\end{array}$ \\
\hline 4 & Democratic & Authoritarian \\
\hline 5 & $\begin{array}{l}\text { Values and respects } \\
\text { individuality }\end{array}$ & $\begin{array}{l}\text { Values } \\
\text { conformity }\end{array}$ \\
\hline 6 & Long term development & $\begin{array}{l}\text { Short term } \\
\text { compliance }\end{array}$ \\
\hline 7 & $\begin{array}{l}\text { Focuses on future } \\
\text { correct acts }\end{array}$ & $\begin{array}{l}\text { Focuses on past } \\
\text { misdeeds }\end{array}$ \\
\hline
\end{tabular}

\section{Strategies for disciplining preschool children}

The following, among other strategies, have been found useful in disciplining preschool children [11, 3]:

(i) Providing routine and structure by letting children know what is expected of them in designated places and at specific times during school hours. For instance, children are taught to put their food basket and bags in designated places on arrival in school every morning.

(ii) Ignoring mild misbehaviour (especially if it is not habitual and would not hurt anyone). This does not mean looking the other way when a child is doing something dangerous or inappropriate, but rather ignoring attention-seeking behavior. The attention should be returned when the child is of good behavior.

(iii) Praises/rewards should be given for appropriate behaviour. When there are several children in the room, the most attention and praise should be given to the children who are following the rules and behaving well. Providing an incentive to behave can turn around misbehavior fast. Rewards help kids to focus on what they need to do to earn privileges, rather than emphasize the bad behavior they are supposed to avoid.

(iv)Inappropriate behaviour should be prevented before occurrence. For instance, giving sufficient materials to children to play/work with rather than hoping they would share would prevent quarrels/fights before they occur.

(iv) Dialogue- helps to understand children's feelings and how they can be helped to behave better. For instance, if children do not do their homework, then they cannot get a star.

(v) Short Time out- This means removing the child from the scene of unacceptable behaviour for a short period to enable him/her calm down. When done correctly, time-out teaches children how to calm themselves down, which is a useful life skill. However, in order for time-out to be effective, children need to have plenty of positive time-in. Then, when they are removed from the situation, the lack of attention will be uncomfortable, and that discomfort could remind them to behave better in the future.

(vi) Consequences- Children should be allowed to experience the consequences of their actions (provided those consequences are not harmful). Natural consequences allow children to learn from their own mistakes. However, the situation should be monitored to ensure that the child does not experience any real danger.

(vii) Setting tangible and intangible limits and enforcing them. This implies setting rules that must be enforced consistently; otherwise, they cannot be effective.

(viii) Redirecting inappropriate behaviour by shifting the child's energy to more acceptable activity. For instance, replacing a book about to be torn with scrap paper would redirect the child's energy to a more acceptable activity.

(ix) Teaching children acceptable ways to express their feelings. They should be taught and encouraged to communicate feeling verbally. When children are taught how to problem-solve, manage their emotions and compromise, they learn how to control and avoid unacceptable behavior. Eventually, they learn that it is okay to be angry but not okay to express it in ways that hurt others such as hit, push and insult.

(x) Modelling prosocial behavior. Adults should never display actions and reactions that they have termed 'unacceptable'. If a child is not allowed to use dirty language or to swear, neither should the teacher.

(xi) Removing privileges- The child is not allowed access to something they love (such as computer game or television) for a while due to 
misbehaviour. A spanking may sting for a few minutes, taking away a privilege hurts longer. This will serve as a reminder not to repeat that mistake.

(xii) Preparing them for transition (that is, rather than stop them abruptly from an activity they enjoy, tell them they would stop in 5 or 10 minutes).

(xiii) Allowing children to be children- There is no point in punishing a baby for crying because he or she is hungry or needs to be cuddled, or a two year old who runs into the road in front of cars because this is what can be expected from children at different ages. Instead, they should be kept safe by holding their hand while walking on the road and removing the possibility of physical danger such as fire, kerosene or medicine bottle.

\section{Conclusion and Recommendation}

The use of corporal punishment as a means of disciplining a child breaches children's fundamental human right. Therefore, children's right to protection from corporal punishment and all other cruel or degrading forms of punishment should be communicated to children and adults. This will be the first and major step towards according this right to all children by adults including teachers and care givers.

Corporal punishment has been found to be a threat to the healthy development and welfare of children, and an ineffective form of discipline. Constructive, non-violent child discipline is needed. Supportive information, resources and guidance for achieving this are available. These alternative methods should be promoted and made readily accessible to families, schools and communities throughout the world.

In order to discipline effectively, teachers and caregivers need to recognize appropriate behaviour for children of different ages. A good knowledge of child psychology would go a long way in meeting this need. It would be necessary to organize trainings and workshops where teachers would be taught to acquire this knowledge and the skills that would enable them to be more effective at their jobs.

Moreover, public awareness about the negative effects of corporal punishment on the child should be raised so that such practices could be stopped. More importantly, appropriate laws should be enacted and enforced in order to stop this barbaric act in the best interest of the child. It is very important that teachers should know that by assaulting children they risk not only dismissal but also prosecution by criminal law, which does not exist in many countries at present.

\section{References}

[1] Gershoff, E. T. \& Grogan-Kaylor, A., "Spanking and Child Outcomes: Old Controversies and New
Meta-Analyses". Journal of Family Psychology, 2016 doi:10.1037/fam0000191.

[2] Wikipedia. "School Corporal Punishment" 2018, Retrieved online on 3rd January, 2019 from https://en.wikipedia.org/wiki/School_corporal_punis hment

[3] American Academy of Child \& Adolescent Psychiatry (AACAP)., "Physical Punishment". 2012. Retrieved online on 19th January, 2018 from https://www.aacap.org/aacap/families_and_youth/fac ts_for_families/FFF-Guide/Physical-Punishment 105. Aspx.

[4] Wikipedia. "Corporal Punishment in the Home". 2017, Retrieved online on 19th January, 2017 from https://en.wikipedia.org/wiki/Corporal_punishment_i n_the_home

[5] Wikipedia. Corporal punishment. 2018, Retrieved online on 19th January, 2018 from https://en.wikipedia.org/wiki/Corporal_punishment

[6] United Nations Committee on the Rights of the Child (UNCRC). UN Doc CRC/C/GC/8, paragraph 29. 2006.

[7] Strauss, M. A. \& Paschall, M. J., (2000). "Corporal Punishment by Mothers and Development of children's cognitive ability: A Longitudinal Study of two nationally representative age cohorts". Journal of Aggressive Maltreatment Trauma, 18, pp. 459483.

[8] Grogan-Kaylor, A., (2004). "The Effects of Corporal Punishment on anti-social behaviour in children". Social Work Research, 28, pp. 153-162.

[9] Poole, S. R., Ushkow, M. C., Nader, P. R., Bradford, B. J., Asbury, J. R., Worthington, D. C., Sanabria, K. E. \& Carruth, T., (1991). "The role of the pediatrician in abolishing corporal punishment in schools". Pediatrics. 88 (1): 162-7.

[10] Greydanus, M. D., (2010). "Corporal Puni,shment in Schools and its Effect on Academic Success: Testimony. Healthy Families and Communities Subcommittee, United States House of Representatives. 15 Apri.

[11] Gonzalez-Mena, J., (2008). Foundations of Early Childhood Education: Teaching Children in a Diverse Society. NY: McGraw-Hill.

[12] Ogando P., Maria J. \& Pells, K., (2015). Corporal Punishment in Schools - Longitudinal Evidence from Ethiopia, India, Peru and Vietnam, 
Innocenti Discussion Papers UNICEF Office of Research - Innocenti, Florence.

[13] Republic of Uganda Ministry of Education \& Sports, (2017). Positive Discipline/ Alternatives to Corporal Punishment Training Manual to end Violence in Schools. Retrieved online on 3rd January, 2019 from https://www.worldvision.org/wpcontent/uploads/201 8/09/3-DREAMS-trainingmanual-to-end-violencein-schools-1.pdf

[14] Global Initiative to End All Corporal Punishment of Children, (2018). Nepal prohibits all corporal punishment of children. Retrieved online on the 6th January, 2018 from https://endcorporalpunishment.org/nepalprohibitsall-corporal-punishment-of-children/

[15] Global Initiative to End All Corporal Punishment of Children, (2018). Nepal prohibits all corporal punishment of children. Retrieved online on the 6th January, 2018 from https://endcorporalpunishment.org/countdown/ 